\title{
Sublethal Effects of Poly (Amidoamine) Dendrimers in Rainbow Trout Hepatocytes
}

\author{
Auclair $\mathrm{J}^{1}$, Morel $\mathrm{E}^{2}$, Wilkinson $\mathrm{KJ}^{2}$, Gagne $\mathrm{F}^{1 *}$ \\ ${ }^{1}$ Aquatic Contaminants Research Division, Environment and Climate Change Canada, 105 McGill, Montréal, QC, Canada \\ ${ }^{2}$ Department of Chemistry, University of Montreal, C.P. 6128, Succ, Centre-Ville, Montreal, Canada H3C 3J7
}

Received: 03 December, 2016; Accepted: 16 December, 2016; Published: 26 December, 2016

*Corresponding author: F. Gagné, Aquatic Contaminants Research Division, Environment and Climate Change Canada, 105 McGill Street, Montreal, Quebec, Canada, E-mail: francois.gagne@canada.ca

\begin{abstract}
The purpose of this study was to examine the toxicity of drug vectors-poly (amidoamine) (PAMAM) dendrimers-to rainbow trout hepatocytes. Primary cultures of rainbow trout hepatocytes were exposed to concentrations of G2, G4, G5 PAMAM dendrimers and a representative antibiotic-minocycline-in municipal effluents for $48 \mathrm{~h}$ at $15^{\circ} \mathrm{C}$. After the exposure period, cells were harvested for the assessment of viability, heat shock protein 70 (HSP70) level and glutathione S-transferase (GST) activity. The results revealed that the PAMAM dendrimers were toxic to rainbow trout hepatocytes, with the G4 and G5 PAMAM dendrimers being 5 times more toxic than the G2 PAMAM dendrimer. In addition, the G4 and G5 PAMAM dendrimers increased HSP70 levels, while the G2 PAMAM dendrimer systematically reduced those levels. The G5 PAMAM dendrimer alone was able to induce GST activity, which is indicative of oxidative stress. Minocycline was found to be toxic to rainbow trout hepatocytes at high concentrations ( $>90 \mu \mathrm{g} / \mathrm{mL}$ ) which are not likely to occur in municipal effluents. The antibiotic also systematically reduced HSP70 levels and GST activity. In conclusion, PAMAM dendrimers are cytotoxic to rainbow trout hepatocytes but acute toxicity occurs at concentrations not expected to be found in hospital and municipal effluents. The sublethal effects of these dendrimers on HSP70 levels and GST activity suggest that chronic effects could also occur.
\end{abstract}

Keywords: Oncorhynchus mykiss; Hepatocytes; PAMAM dendrimers; Cell viability; Heat Shock Proteins; Glutathione S-Transferase

\section{Introduction}

Nanotechnology has under gone exponential development which has reached many sectors of our economy. NMs have found many applications, from electronic devices, paints/dyes, cosmetics and personal products, to biomedical uses such as imaging and drug and gene delivery strategies. Any product at the nanoscale with at least one dimension between 1 and 100 nanometers (nm) is considered a NM. Compounds produced at the nanoscale offer new and interesting emerging properties with tremendous potential for commercial applications. For example, the use of nanoparticles or nano-vectors can permit enhanced delivery of a given drug within the body and can target drug release to specific sites in the body. However, the increasing use of NMs has raised concerns about the inadvertent release of such products into the environment and potential impacts on aquatic ecosystems [1]. The toxicity of nanomaterials arises from the cumulative effects of four basic properties associated with colloids: 1) the leaching of low-molecular-weight molecules or ions, 2) the geometry (size and shape) of the NMs including their aggregates, 3) the surface properties (reactivity), and 4) the vector effect. The last property has been extensively studied in connection with the development of drug, gene and peptide delivery systems in therapeutics. Some NMs have the ability to interact with xenobiotics (drugs) and can increase their bioavailability and toxicity by promoting their internalization in tissues/cells [2]. For example, the cytotoxicity of Adriamycin to Chinese hamster cell line DC3F increased when it was associated with cyanoacrylate nanoparticles. In addition, an Adriamycinresistant hamster cell line became more sensitive to the drug when it was associated with cyanoacrylate nanoparticles, which provides evidence of vector effect. From an environmental risk assessment perspective, it is important to gain a better understanding of the toxicity associated with NMs used as drug delivery "devices" before seeking to determine the vector effect in contaminated environments.

The development and use of poly PAMAM dendrimers for targeted and enhanced drug and gene delivery have been extensively examined $[3,4]$. The interest in these dendritic NMs stems from their structural properties including uniformity, size, shape, monodispersity and functionalized surfaces [5]. Dendrimers are composed of an initiator amine core (-NH2) with attached amidoamine units that are radially distributed around the core (Figure 1). Each successive branching that forms a surface layer is termed a generation (G). Full-generation dendrimers (G1, G2, G3, etc.) have cationic amine-terminated groups at physiological $\mathrm{pH}$, while half-generation dendrimers (G2.5, G3.5) have anionic carboxylic moieties at physiological pH. Finally, each successive generation has twice the number of terminal groups and increased diameter size. Cationic dendrimers have been shown to exhibit cytotoxicity and haemolysing properties which are dependent on size and surface charge (Zeta potential) [6]. It appears that dendrimers produce small "nanoholes" or "nanopores" in membranes, which can perturb membrane potential integrity and permeability. Thus, the toxicity of 
dendrimers could be due to their surface properties in addition to their vector properties.

Studies on the toxicity of PAMAM dendrimers to non-target species are relatively scarce at present and the environmental risk of these NMs in not well understood at the present time. Hence the examination of cytotoxicity of PAMAM dendrimers at both the lethal and sublethal levels in fish hepatocytes is of relevance in the understanding of the potential toxicity of these compounds in aquatic ecosytems. G4 PAMAM dendrimers were found to decrease growth and larval development in zebra fish embryos [7]. In an earlier study, G4 PAMAM dendrimers were associated with reduced algal survival, enhanced oxygen production and stimulation of photosystem II reaction centre activity [8], which points to the formation of reactive oxygen species and oxidative stress. Depending on their size and shape, nanoparticles may induce interactions in the protein space domain leading to protein denaturation. The heat shock proteins of the $70 \mathrm{kDa}$ family (HSP70) are stress proteins that are involved in stabilizing protein conformation [9]. This process is clearly energy demanding since these chaperone proteins require ATP to function. For example, it was estimated that one heat shock protein requires up to 100 moles of ATP to re-fold denatured rhodanase protein [10]. Heat shock proteins were also shown to respond to oxidative stress [9]. Rainbow trout yearlings exposed to cadmium-based quantum dots and to dissolved cadmium showed increased HSP70 levels and oxidative damage [11]. However, correction of HSP70 levels against oxidative stress markers (oxidized proportion of metallothioneins or lipid peroxidation) failed to remove the inducing effects of the quantum dots, suggesting that interactions other than oxidative stress were at play. Oxidative stress and xenobiotic conjugation can be conveniently monitored on the basis of glutathione S-transferase (GST) activity. GST requires reduced glutathione (GSH) in order to function, which can be a limiting factor during oxidative stress. The formation of oxygen adducts to molecules during oxidative stress could also be neutralized by conjugation with GSH. For example, GST activity was used as a marker of oxidative stress in marine mussels exposed to cadmium-based quantum dots [12] Exposure to $10 \mu \mathrm{g} / \mathrm{L}$ cadmium-based quantum dots increased oxidative stress and GST activity, while dissolved cadmium at the same concentration failed to induce GST activity. Given that PAMAM dendrimers are likely to be released into the environment in wastewater effluent containing many pollutants such as antibiotics, the toxicity of a representative antibiotic to fish liver cells is relevant. Tetracyclines (minocycline) are commonly found in hospital and municipal wastewaters [13]. Minocycline levels were found to range from non-detectable to $530 \mu \mathrm{g} / \mathrm{L}$ in hospital effluents and from 95 to $920 \mu \mathrm{g} / \mathrm{L}$ in wastewater treatment plant effluents. In addition, these compounds are continuously released in to the environment from municipal effluents. This could lead to accumulation in non-target organisms if exposure to such compounds exceeds their capacity to eliminate them.

The purpose of this study was to investigate the cellular toxicity of G2, G4 and G5 PAMAM dendrimers and of minocycline in rainbow trout hepatocytes. Cytotoxicity and the levels of stress proteins (HSP70) and GST activity were also determined in order to evaluate the toxicity and mechanisms of action of these NMs in fish hepatocytes.

\section{Methods \\ Preparation and exposure of rainbow trout hepatocytes}

Second, fourth and fifth generation PAMAM dendrimers were purchased from Sigma Chemical Company (Ontario, Canada). They were diluted in High Quality water at $200 \mathrm{mg} /$ $\mathrm{mL}$ to perform dynamic light scattering (DLS) analysis in order to measure particle size distribution and Zeta potential and hepatocyte exposure. The analysis was done using a DLS) instrument with a gel electro mobility option (Wyatt-Instrument Mobius, 532-nm laser). Zeta potential was determined from gel mobility data as described in Domingos et al., 2013 [14]. The measurements were made at $1 \mathrm{mg} / \mathrm{mL}$ under identical conditions as in High Quality water. The analytical performance of the instrument was validated with NIST polystyrene standard beads (42 $\mathrm{nm}$ diameter) and a Zeta potential standard solution (Ostuka mobility Standard, lot No. 302013). Primary cultures of rainbow trout (Oncorhynchus mykiss) were prepared using a perfusion method with saline citrate and albumin [15]. Briefly, young-of-the-year (8- to $10-\mathrm{cm}$ fork length) rainbow trout (3 livers pooled) were used. After the trout were anesthetized with $25 \mathrm{mg} / \mathrm{L}$ tricaine buffered to $\mathrm{pH} 7.4$ with $1 \mathrm{M} \mathrm{NaHCO3}$, the excised livers were perfused with $10 \mathrm{mM}$ citrate in $125 \mathrm{mM}$ $\mathrm{NaCl}, \mathrm{pH} 7.2$, at $4^{\circ} \mathrm{C}$ until the liver tissue acquired a light brown coloration. The livers were then minced and placed in $10 \mathrm{~mL}$ of citrate perfusion media containing $0.5 \%$ serum bovine albumin. The suspension was stirred slowly with a magnetic stirring bar at 20-40 rpm for $30 \mathrm{~min}$ at room temperature. After this period, the suspension was passed through a cell extraction sieve (40$\mu \mathrm{m}$ diameter mesh, Sigma Chemical Company) and the cells were washed in phosphate-buffered saline (PBS: $140 \mathrm{mM} \mathrm{NaCl}, 5 \mathrm{mM}$ $\mathrm{KH} 2 \mathrm{PO} 4,5 \mathrm{mM}$ NaHCO3, $1 \mathrm{mM}$ glucose, $\mathrm{pH}$ 7.4) containing $0.1 \%$ serum bovine albumin, followed by centrifugation $(200 \times \mathrm{g}$ for 5 $\mathrm{min}$ )/ re suspension 3 to 4 times until a clear supernatant (free of debris) was obtained. A portion of the cell suspension was stained with $0.004 \%$ trypan blue in PBS for the determination of cell concentration and viability. The cells were counted and viability was determined (live cells remain transparent and dead ones are blue) using a hematocytometer under a microscope at 200X enlargement. Hepatocytes were plated in 48-well microplates at a density of $0.5 \times 106$ viable cells $/ \mathrm{mL}$ ( 6 replicate wells per treatment) in Liebovitz (L-15) cell culture media containing $10 \mathrm{mM}$ HEPES-NaOH, pH 7.4, 50 units penicillin, $50 \mu \mathrm{g} / \mathrm{mL}$ streptomycin and $0.1 \mu \mathrm{g} / \mathrm{mL}$ amphotericin B. The cells were exposed to increasing concentrations of G2, G4 and G5 PAMAM dendrimers and to minocycline at 1.6, 8, 40 and $200 \mu \mathrm{g} / \mathrm{mLfor} 48$ $\mathrm{h}$ at $15^{\circ} \mathrm{C}$ in a saturated humidity atmosphere. At the end of the exposure period, the microplates were centrifuged at $250 \times \mathrm{g}$ for 3 to $5 \mathrm{~min}$ and the exposure medium was removed by aspiration. Cells were suspended in PBS (without albumin) for cell density and viability assessments. Relative cell density was determined by measuring the absorbance at $600 \mathrm{~nm}$. 


\section{Cell viability assessment}

Hepatocyte viability was determined by the fluorescein dye retention assay as described elsewhere [15]. A portion $(20 \mu \mathrm{L})$ of the cell suspension was mixed with $180 \mu \mathrm{L}$ of $10 \mu \mathrm{M}$ fluorescein diacetate in PBS containing $1 \mathrm{mM}$ glucose and kept in darkcoloured microplates for $20 \mathrm{~min}$ at $20^{\circ} \mathrm{C}$. The microplate was centrifuged at $250 \times \mathrm{g}$ for $5 \mathrm{~min}$ and the supernatant removed. The cells were then resuspended in $200 \mathrm{uL}$ of phosphate-buffered saline, and fluorescence was measured at $485 \mathrm{~nm}$ excitation and $520 \mathrm{~nm}$ emission using a microplate reader (Chameleon II, Bioscience, USA). A positive control (100\% mortality) was prepared by adding cells to separate wells containing 20\% DMSO to completely permeabilize the cells. The data were normalized to controls and expressed as a fold change (reduction) in fluorescence.

HSP70 levels were determined using an enzyme-linked immunoassay as described earlier (Louis et al., 2010) [11]. The hepatocytes were first homogenized using a Teflon pestle tissue/ cell grinder ( 4 passes at $4^{\circ} \mathrm{C}$ ) and centrifuged at 12,000 $\times \mathrm{g}$ for $20 \mathrm{~min}$ at $4^{\circ} \mathrm{C}$. The supernatant (S12) was diluted to 1 $\mu \mathrm{g}$ total protein in $50 \mathrm{mM}$ sodium carbonate buffer at $\mathrm{pH}$ 9.6. Total protein was determined using the Coomassie brilliant blue protein binding assay with serum bovine albumin for calibration [16]. The material was added to high-binding microplate wells (Immulon-4 microplate) and held overnight at $4^{\circ} \mathrm{C}$. Afterwards, the wells were rinsed with $200 \mu \mathrm{L}$ of PBS twice and incubated with PBS containing $1 \%$ albumin for $30 \mathrm{~min}$ at $20^{\circ} \mathrm{C}$ to block the remaining sites. The wells were washed with $200 \mu \mathrm{L}$ of PBS, and $100 \mu \mathrm{L}$ of HSP72 polyclonal antibody (recombinant human HSP72 IgG SPA-812; Stressgen, USA) diluted1:1,000 in PBS containing $0.5 \%$ albumin was added to each well. The wells were incubated at $37^{\circ} \mathrm{C}$ for $60 \mathrm{~min}$. The cells were washed 3 times in PBS, and $100 \mathrm{uL}$ of the secondary antibody (rabbit anti-IgG linked with peroxidase) diluted 1:5,000 in PBS containing 0.5\% albumin was added and incubated for $30 \mathrm{~min}$ at $20^{\circ} \mathrm{C}$. The wells were washed 3 times in PBS $(200 \mu \mathrm{L})$, and peroxidase activity was determined with $1 \mathrm{uM}$ luminol and $10 \mu \mathrm{M}$ hydrogen peroxide. Luminescence was measured at the initial mixing and monitored for up to 20 min using a luminescence microplate reader (Chameleon II, Bioscience, USA). The data were expressed as peroxidase activity (increase in luminescence)/min. GST activity was determined in the S12 fraction of the supernatants using the colorimetric assay procedure with reduced GSH and 1-chloro-2, 4-dinitrobenzene co-substrates [17]. The data were expressed on the basis of the rate of increase in absorbance at $340 \mathrm{~nm} /$ ( $\mathrm{min} \times \mathrm{mg}$ proteins).

\section{Data analysis}

The hepatocytes were exposed to $n=6$ replicates of each concentration of the tested compounds. The toxicity of the PAMAM dendrimers and of minocycline was expressed in terms of toxicity thresholds, which corresponds to the geometric mean of the lowest significant effects concentration (LSEC) and the no-effect concentration $(\mathrm{NEC}): \mathrm{TT}=(\mathrm{LSEC} \times \mathrm{NEC}) 1 / 2$. The data were checked for homogeneity of variance and normality using Levene's test and the Shapiro-Wilk test, respectively. Analysis of variance was performed, and critical differences were determined using Dunnett's t test. Correlation analysis was also performed using Pearson's product-moment procedure and the tests were performed using the Statistic software package (version 8.).

\section{Results and Discussion}

The prepared dendrimers consisted of the G2, G4 and G5 PAMAM dendrimers which have a poly diamine core and described in Figure 1. The G2, G4 and G5 dendrimers have a theoretical diameter of 2.9.4.5 and $5.4 \mathrm{~nm}$, respectively (Table1). Although the size of these dendrimers did not change much, the number of functional amine groups $(-\mathrm{NH} 4+)$ at their surface readily increased from 16 to 128 for G2 and G5 dendrimers, respectively. This change was accompanied by an increase in molecular weight in such a manner that an equivalent $20 \mu \mathrm{g} /$ $\mathrm{mL}$ solution consisted of $6,1.4$ and $0.7 \mu \mathrm{M}$ for G2, G4 and G5 PAMAM dendrimers, respectively. Compared to the same amount of minocycline, the dendrimer concentrations were at least one order of magnitude lower than the antibiotic, i.e., minocycline was in excess compared to the PAMAM dendrimers. Given the

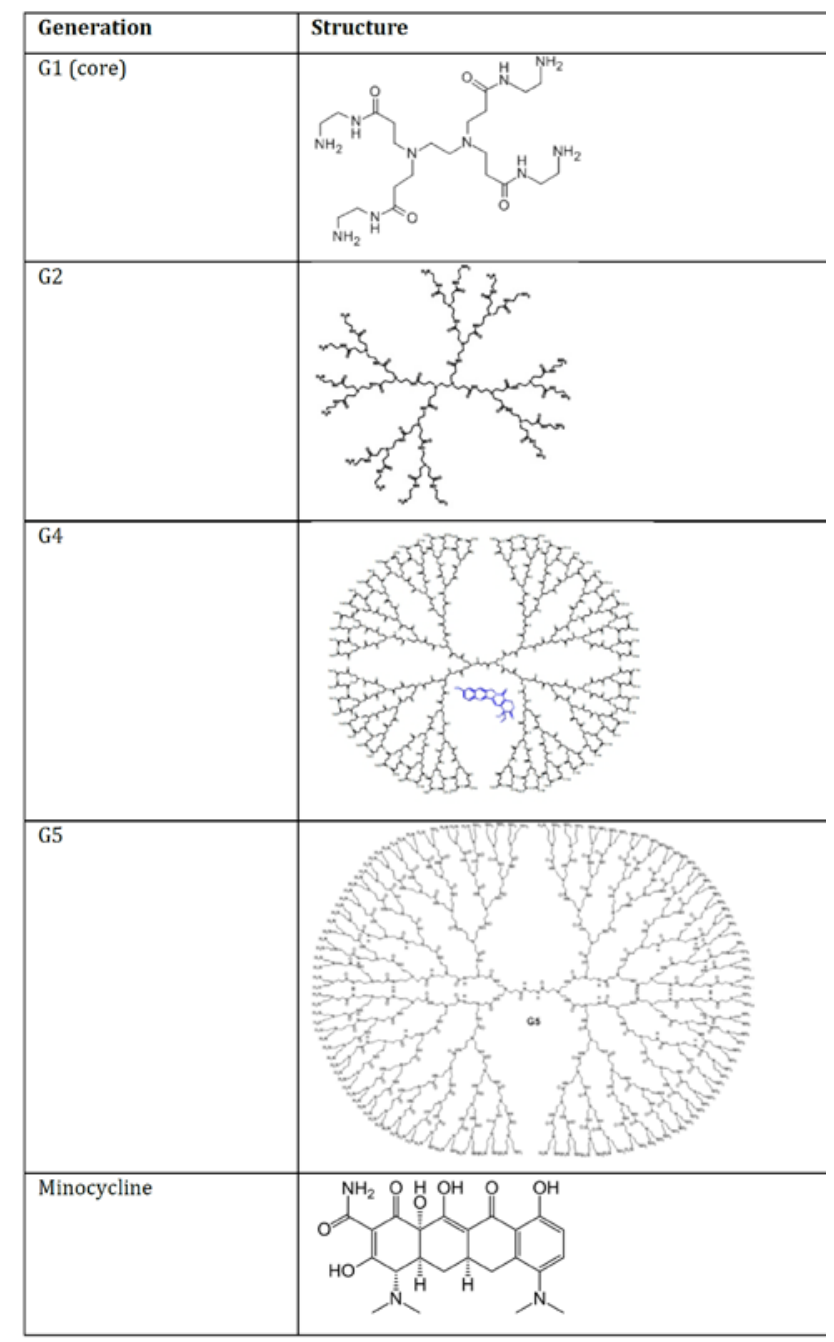

Figure 1: Molecular structure of PAMAM dendrimers and minocycline 
pKa values ( 5 and 9.5) for the 2 amine groups of minocycline, the molecule can be assumed to be cationic at physiological $\mathrm{pH}$ as is the case for dendrimers. This is consistent with what is known about these types of drug vectors, which have high surface area chemistries permitting interaction of drugs at the surface. However, dendrimers can induce pore formation, permitting higher diffusion of contaminants into cells [18]. These properties complicate the classical risk assessment paradigm because nanoparticles could change the bioavailability of contaminants in the environment.

The effects of PAMAM dendrimers of increasing size were examined in rainbow trout hepatocytes (Figure 2). G4 and G5 PAMAM dendrimers were found to be more toxic than G2 PAMAM dendrimers, with toxicity thresholds of $3.6 \mu \mathrm{g} / \mathrm{mL}$ compared to $20 \mu \mathrm{g} / \mathrm{mL}$. Minocycline was the least toxic test substance; it caused a significant drop in cell viability at $200 \mu \mathrm{g} / \mathrm{mL}$, giving a toxicity threshold of $90 \mu \mathrm{g} / \mathrm{mL}$. This is in keeping with other studies which showed that dendrimer toxicity is size- and surface charge-dependent $[6,19]$. The haemolysing potential and the cytotoxicity observed in erythrocytes in creased with higher generation PAMAM dendrimers (G5 and G6). However, the initial positive Zeta potential value in water dropped to a negative value in cell culture media, which points to an interaction with cell culture media components. Increasing cationic charge at the surface of PAMAM dendrimers was proportionally toxic to Daphnia magna and rainbow trout gonad (RTG-2) cell lines [20]. Toxicity was also related to the Zeta potential of G4 to G6 PAMAM dendrimers in the culture media, indicating that toxicity was related to the surface properties (i.e., number of surface groups) of the nanoparticle. Although the Zeta potential decreased in aquarium water, there was no indication of aggregate formation and the dendrimers were shown to influence the innate immunity in zebrafish embryos exposed to G3 and G4 PAMAM dendrimers [21].

The sublethal effects of PAMAM dendrimers were also examined by monitoring HSP70 levels and GST activity (Figures 3 and 4). For protein chaperone HSP70, the dendrimers tended to decrease HSP70 levels, with the exception of G4 dendrimers which increased their levels. The decrease in HSP70 levels occurred at the lowest tested concentrations of the G2 and G5 PAMAM dendrimers. The lowest concentration of minocycline reduced HSP70 levels but with less potency than the dendrimers, however the decrease in HSP70 levels was dampened at 8 and $40 \mu \mathrm{g} / \mathrm{mL}$. The activity of GST, a marker enzyme for oxidative stress and xenobiotic conjugation, increased in response to the lowest concentration of G5 PAMAM dendrimer and decreased at the higher dendrimer concentrations. G2 andG4 dendrimers and minocycline reduced GST activity, but G4 PAMAM dendrimer was more potent than the other dendrimers (G2 and G5) in reducing GST activity. Based on correlation analysis, the decrease in HSP70 levels and GST activity was mostly associated with decreased cell viability. Cell viability was significantly correlated with HSP70 $(\mathrm{r}=0.52 ; \mathrm{p}<0.01)$ and GST activity $(\mathrm{r}=0.45 ; \mathrm{p}<0.05)$ for $\mathrm{G} 2$ PAMAM dendrimer. For G4 PAMAM dendrimer, cell viability was also correlated with HSP70 $(\mathrm{r}=-0.5 ; \mathrm{p}<0.01)$ and GST activity $(\mathrm{r}$ $=0.78 ; \mathrm{p}<0.001)$. GST activity was significantly correlated with
HSP70 only after correcting against loss of cell viability (residuals) at $\mathrm{r}=0.38(\mathrm{p}<0.05)$, which suggests that oxidative stress was involved in HSP70 expression, in part at least. For the G5 PAMAM dendrimer, cell viability was significantly correlated with HSP70 level $(\mathrm{r}=-0.45 ; \mathrm{p}=0.01)$ and GST activity $(\mathrm{r}=0.61 ; \mathrm{p}<0.001)$. In the case of minocycline, cell viability was only correlated with GST activity ( $r=0.46 ; \mathrm{p}=0.01)$. GST activity (corrected against cell viability) and HSP70 levels were significantly correlated at ( $\mathrm{r}=-$ 0.66 ( $p<0.001)$. Minocycline is recognized as having antioxidant properties in addition to bactericidal activity as shown by reduced lipid peroxidation in brain tissues [22]. In another study, GST induction by cypermethrin was prevented by minocycline inperipheral red blood cells in the rat [23].

To best of our knowledge, this is the firstreport on the influence of PAMAM dendrimers on HSP70 levels. Decreased expression of HSP70 could render cells less able to defend against changes

Table 1: Physico-chemical characteristics of minocycline and, G2 and G5 dendrimers

\begin{tabular}{|c|c|c|c|c|c|}
\hline Compound & $\begin{array}{l}\text { MW g/ } \\
\text { mol }\end{array}$ & Formula & $\begin{array}{l}\# \\
\text { surface } \\
\text { groups }\end{array}$ & $\begin{array}{l}\text { Diameter } \\
(\mathrm{nm})\end{array}$ & $\begin{array}{l}\text { Zeta } \\
\text { Potential }\end{array}$ \\
\hline Minocycline & 494 & $\mathrm{C}_{23} \mathrm{H}_{27} \mathrm{~N}_{3} \mathrm{O}_{7} \cdot \mathrm{HCl}$ & -- & & - \\
\hline G2 PAMAM & 3256 & $\begin{array}{l}{\left[\mathrm{NH}_{2}\left(\mathrm{CH}_{2}\right)_{2} \mathrm{NH}_{2}\right]:(\mathrm{G}} \\
=2) ; \\
\text { PAMAM }\left(\mathrm{NH}_{2}\right)_{16}\end{array}$ & 16 & 2.9 & 16.6 \\
\hline $\begin{array}{l}\text { G4 } \\
\text { PAMAM }\end{array}$ & 14215 & $\begin{array}{l}{\left[\mathrm{NH}_{2}\left(\mathrm{CH}_{2}\right)_{2} \mathrm{NH}_{2}\right]:(\mathrm{G}} \\
=4) ; \\
\text { PAMAM }\left(\mathrm{NH}_{2}\right)_{64}\end{array}$ & 64 & 4.5 & 32.25 \\
\hline G5 PAMAM & 28826 & $\begin{array}{l}{\left[\mathrm{NH}_{2}\left(\mathrm{CH}_{2}\right)_{2} \mathrm{NH}_{2}\right]:(\mathrm{G}} \\
=5) ; \\
\text { PAMAM }\left(\mathrm{NH}_{2}\right)_{128}\end{array}$ & 128 & 5.4 & 36 \\
\hline
\end{tabular}

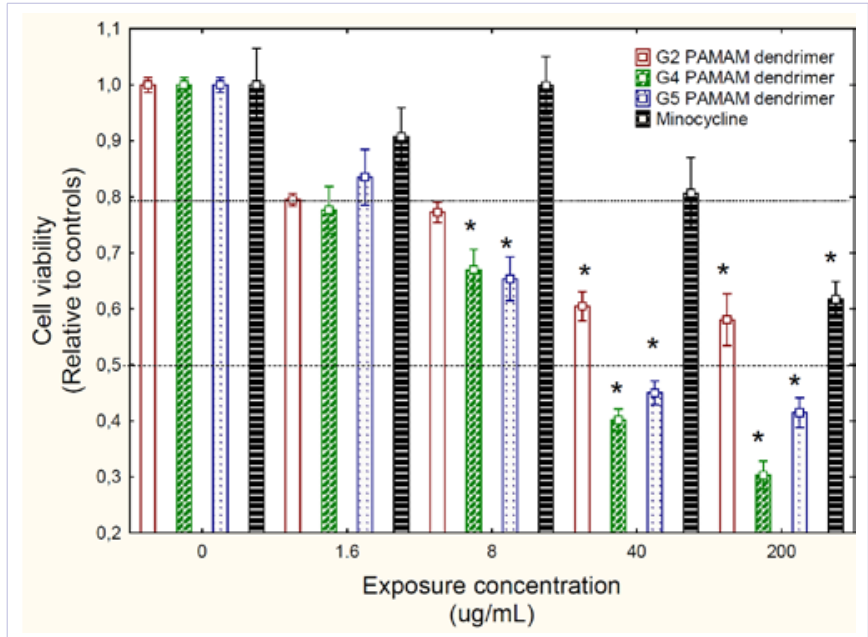

Figure 2: Change in cell viability in trout hepatocytes exposed to PAMAM dendrimers and minocycline. Rainbow trout were exposed to G2, G4 and G5 PAMAM dendrimers and minocycline for $48 \mathrm{~h}$ at $15^{\circ} \mathrm{C}$. The star * symbol indicates a significant difference from the controls at $\alpha<0.05$. 


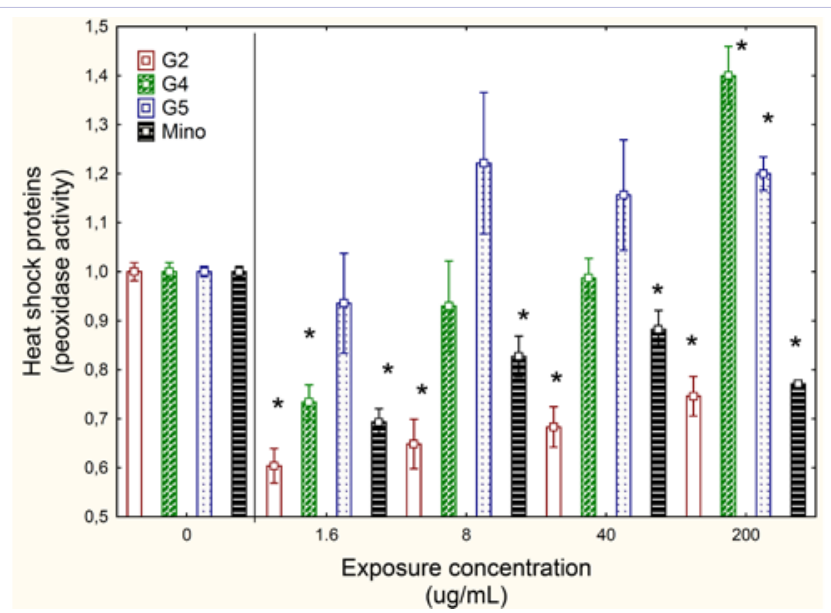

Figure 3: Change in heat shock proteins in trout hepatocytes exposed to dendrimers of increasing sizes. Trout hepatocytes were exposed to increasing concentrations of G2, G4 and G5 PAMAM dendrimers and minocycline for $48 \mathrm{~h}$ at $15^{\circ} \mathrm{C}$. The star * symbol indicates significance at $\alpha=0.05$.

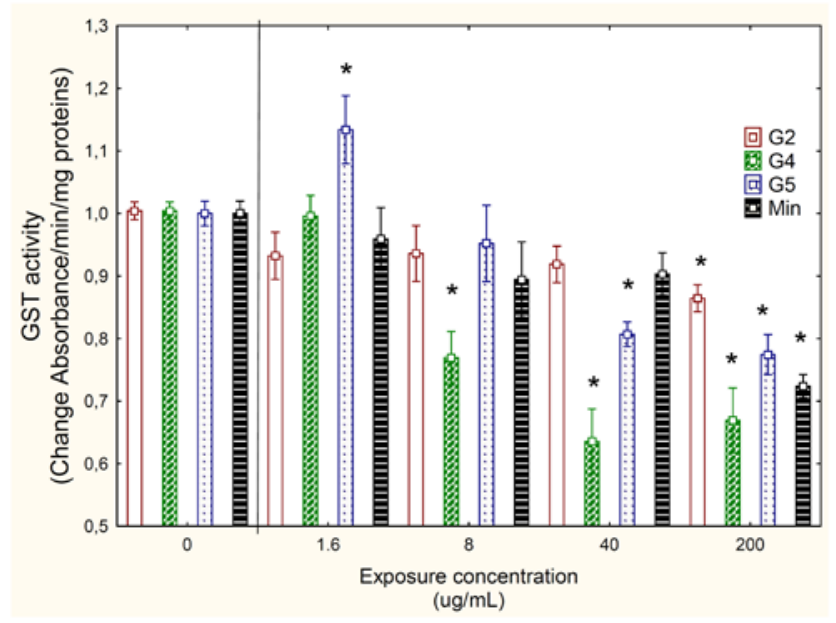

Figure 4: Change in GST activity of trout hepatocytes exposed to dendrimers of increasing size. Rainbow trout were exposed to G2, G4, G5 PAMAM dendrimers and minocycline for $48 \mathrm{~h}$ at $15^{\circ} \mathrm{C}$. The star * symbol indicates significant difference from the controls at $\alpha<0.05$.

in protein scaffolding induced by nanoparticles. For example, strong expression of HSP70 occurred in trout hepatocytes exposed to aged cadmium-based quantum dots [24]. Induction of HSP70 was the strongest response to these nanoparticles and involved metallothioneins and labile zinc in cells, suggesting that the release of toxic cadmium ions was at play, at least. It is noteworthy that an increase in HSP70 was also associated with oxidative stress [25]. GST activity is a marker of oxidative stress as well as the conjugation of polar compounds. GST activity was marginally negatively correlated with HSP70 levels $(r=-0.31$; $\mathrm{p}=0.09$ ) for the G4 PAMAM dendrimer, the only dendrimer that induced HSP70. Decreased GST activity could also result from the depletion of reduced GSH in cells undergoing oxidative stress [26]. Induction of HSP70 was also associated with oxidative stress in freshwater musselse xposed to zinc oxide nanoparticles
[27] and in zebra fish embryos exposed to C60 fullerene [28]. In a study involving G4, G5 and G6 PAMAM dendrimers, increased production of reactive oxygen radicals and an increase in genotoxicity were observed in fish hepatocellular carcinoma cell lines [29]. The increase in HSP70 levels and the concomitant decrease in GST activity in hepatocytes exposed to G4 and G5 PAMAM dendrimers maybe attributable to oxidative stress. This is consistent with the decrease in HSP70 levels in hepatocytes exposed to minocycline (known to act as an antioxidant), which was not related to decreased cell viability. In conclusion, PAMAM dendrimers were toxic to rainbow trout hepatocytes, with the G4 and G5 dendrimersbeing 5 times more toxic than G2 dendrimer. The G4 and G5 PAMAM dendrimers increased the levels of HSP70, while the G2 dendrimersystematically reduced those levels. Only the G5 dendrimer was able to induce GST activity indicative of oxidative stress. Minocycline was less toxic to rainbow trout hepatocytes than the dendrimers and systematically reduced the levels of HSP70 and GST activity.

\section{Acknowledgements}

This study was supported by the Chemical Management Plan of Environment and Climate Change Canada. The technical assistance of Joana Kowalczyk is duly recognized.

\section{References}

1. Gagné F, Gagnon C, Blaise C. Aquatic nanotoxicology: A review. Current Top. Toxicol. 2008a;4(1):14.

2. Kubiak C, Couvreur P, Manil L, Clausse B. Increased cytotoxicity of nanoparticle-carried Adriamycin in vitro and potentiation by verapamil and amiodarone. Biomaterials. 1989;10(8):553-6.

3. Yang Y, Sunoqrot S, Stowell C, Ji J, Lee CW, Kim JW, et al. Effect of size, surface charge, and hydrophobicity of poly (amidoamine) dendrimers on their skin penetration. Biomacromolecules. 2012;13(7):21542162. doi: $10.1021 / \mathrm{bm} 300545 \mathrm{~b}$.

4. Abbasi E, Aval SF, Akbarzadeh A, Milani M, Nasrabadi HT, Joo SW, et al. Dendrimers: synthesis, applications, and properties. Nanoscale Res Lett. 2014; 9(1): 247. doi: 10.1186/1556-276X-9-247.

5. Svenson S, Tomalia DA. Dendrimers in biomedical applications-reflections on the field. Adv Drug Deliv Rev. 2005;57(15):2106-29. doi: 10.1016/j.addr.2005.09.018.

6. Jain K, Mehra NK, Jain NK. Potentials and emerging trends in nano pharmacology. Curr Opin Pharmacol. 2014;15:97-106. doi: 10.1016/j. coph.2014.01.006.

7. King Heiden TC, Dengler E, Kao WJ, Heideman W, Peterson RE. Developmental toxicity of low generation PAMAM dendrimers in zebra fish. Toxicol Appl Pharmacol. 2007;225(1):70-9. doi: 10.1016/j. taap.2007.07.009.

8. Petit AN, Eullaffroy P, Debenest T, Gagné F. Toxicity of PAMAM dendrimers to Chlamydomonas reinhardtii. Aquat Toxicol. 2010;100(2):18793. doi: 10.1016/j.aquatox.2010.01.019.

9. El Golli-Bennour E, Bacha H. Hsp70 expression as biomarkers of oxidative stress: mycotoxins' exploration. Toxicology. 2011;287(1-3):17. doi: 10.1016/j.tox.2011.06.002.

10. Martin, J, Langer T, Boteva R, Schramel A, Horwich AL. Chaperoninmediated protein folding at the surface of groEL through a 'moltenglobule'-like intermediate. Nature. 1991;352(6330):36-42. doi: $10.1038 / 352036 \mathrm{a} 0$. 
11.Louis S, Gagné F, Auclair J, Turcotte P, Gagnon C, Émond C. The characterization of the behaviour and gill toxicity of $\mathrm{CdS} / \mathrm{CdTe}$ quantum dots in rainbow trout (Oncorhynchus mykiss). Int.J. Biomed. Nanosci. Nanotech. 2010;1(1): 52-69.

12. Rocha TL, Gomes T, Mestre NC, Cardoso C, Bebianno MJ. Tissue specific responses to cadmium-based quantum dots in the marine mussel Mytilus galloprovincialis. Aquat Toxicol. 2015;169:10-8. doi: 10.1016/j.aquatox.2015.10.001.

13. Pena A, Paulo M, Silva LJ, Seifrtová M, Lino CM, Solich P. Tetracycline antibiotics in hospital and municipal wastewaters: a pilot study in Portugal. Anal Bioanal Chem. 2010;396(8):2929-36. doi: 10.1007/ s00216-010-3581-3.

14. Domingos RF, Rafiei ACZ, Monteiro BCE, Khan MAK, Wilkinson KJ. Agglomeration and dissolution of zinc oxide nanoparticles: role of $\mathrm{pH}$, ionic strength and fulvic acid. Environ. Chem. 2013;10(4):306-312.

15.Gagné F. Acute toxicity assessment of liquid samples with primary cultures of rainbow trout hepatocytes. In Small-scale Freshwater Toxicity Investigations,(C.Blaise and J.-F.Férard, Eds.). 2005;1:453-472. Netherlands.

16. Bradford MM. A rapid and sensitive method for the quantitation of microgram quantities of protein utilizing the principle of protein-dye binding. Anal.Biochem. 1976;72:248-254.

17. Boryslawskyj M, Garrood AC, Pearson JT. Elevation of glutathioneS-transferase activity as a stress response to organochlorine compounds in the freshwater mussel Sphaerium corneum. Mar. Environ. Res. 1988;24(1-4):101-104. doi:10.1016/0141-1136(88)90263-2.

18.Zhang J, Jing B, Regen SL. Kinetic evidence for the existence and mechanism of formation of a barrel stave structure from pore-forming dendrimers. J. Am. Chem. Soc. 2003;125(46): 13984-13987. doi: 10.1021/ ja036390h.

19. Mukherjee SP, Davoren M, Byrne HJ. In vitro mammalian cytotoxicological study of PAMAM dendrimers - towards quantitative structure activity relationships. Toxicol. In Vitro. 2010;24(1):169-177. doi: 10.1016/j.tiv.2009.09.014.

20. Naha PC, Davoren M, Casey A, Byrne HJ. An ecotoxicological study of poly (amidoamine) dendrimers-toward quantitative structure activ- ity relationships. Environ. Sci. Technol. 2009;43(17): 6864-6869. doi: 10.1021/es901017v.

21. Oliveira E, Casado M, Faria M, Soares AM, Navas JM, Barata C, et al. Transcriptomic response of zebrafish embryos to polyaminoamine (PAMAM) dendrimers. Nanotoxicology. 2014;8 Suppl 1:92-9. doi: 10.3109/17435390.2013.858376.

22. Kraus RL, Pasieczny R, Lariosa-Willingham K, Turner MS, Jiang A, Trauger JW. Antioxidant properties of minocycline: neuroprotection in an oxidative stress assay and direct radical-scavenging activity. J. Neurochem. 2005;94(3): 819-827. doi :10.1111/j.14714159.2005.03219.x.

23. Tripathi P, Singh A, Agrawal S, Prakash O, Singh MP. Cypermethrin alters the status of oxidative stress in the peripheral blood: relevance to Parkinsonism. J Physiol Biochem. 2014;70(4):915-24. doi: 10.1007/ s13105-014-0359-7.

24. Gagné, F, Maysinger D, André C, Blaise C. Cytotoxicity of aged cadmium-telluride quantum dots to rainbow trout hepatocytes. Nanotoxicology. 2009;2(3) :113-120.

25. El Golli-Bennour E, Bacha H. Hsp70 expression as biomarkers of oxidative stress: mycotoxins' exploration. Toxicology. 2011;287(1-3):17. doi: 10.1016/j.tox.2011.06.002.

26. Bagnyukova TV, Chahrak OI, Lushchak VI. Coordinated response of goldfish antioxidant defenses to environmental stress. Aquat Toxicol. 2006;78(4):325-31. doi: 10.1016/j.aquatox.2006.04.005.

27. Gagnon C, Pilote M, Turcotte P, André C, Gagné F. Effects of exposure to zinc oxide nanoparticles in freshwater mussels in the presence of municipal effluents. Invert.Surv.J. 2016;13:140-152.

28. Usenko CY, Harper SL, Tanguay RL. 2008. Fullerene C60 exposure elicits an oxidative stress response in embryonic zebrafish. Toxicol Appl Pharmacol. 2008;229(1): 44-55. doi: 10.1016/j.taap.2007.12.030.

29. Naha PC, Byrne HJ. Generation of intracellular reactive oxygen species and genotoxicity effect to exposure of nanosized polyamidoamine (PAMAM) dendrimers in PLHC-1 cells in vitro. Aquat Toxicol. 2013 May 15;132-133:61-72. doi: 10.1016/j.aquatox.2013.01.020. 